\title{
The Social Engagement of Social Science
}


A series in three volumes

Volume I: The Socio-Psychological Perspective

Volume II: The Socio-Technical Perspective

Volume III: The Socio-Ecological Perspective

The University of Pennsylvania Press joins the Editors in expressing thanks to the Ecology of Work Conferences for their generosity in supporting the production of these volumes and to the Busch Center for underwriting the publication. 


\section{The Social}

Engagement of

Social Science

\section{A Tavistock Anthology}

Edited by Eric Trist

and Hugh Murray

Assistant Editor: Beulah Trist

Volume II:

The Socio-Technical Perspective

University of Pennsylvania Press

Philadelphia 
Copyright (C) I 993 by the University of Pennsylvania Press All rights reserved

Permission is acknowledged to reprint portions and excerpts from published materials:

L. Davis. "The Coming Crisis for Production Management." International Journal of Production Research, 9 (1971): 65-82.

L. Davis and S. Sullivan. "A Labor-Management Contract and the Quality of Working Life." Journal of Occupational Behaviour, I (1980): 29-4I.

F. Emery. Futures We Are In. Leiden: Martinus Nijhoff, 1976.

F. Emery and E. Thorsrud. Democracy at Work. Leiden: Martinus Nijhoff, 1976.

P.G. Herbst. Alternatives to Hierarchies. Leiden: Martinus Nijhoff, 1976.

G. Morgan. "Organizational Choice and the New Technology." In Learning Works: Searching for Organizational Futures. Edited by S. Wright and D. Morley. Toronto: ABL Group, Faculty of Environmental Studies, York University, 1989.

P. Hill. Towards a New Philosophy of Management. London: Gower Press, I97I.

C.H. Pava. Managing New Office Technology: An Organizational Strategy. New York: Free Press, 1983 .

E. Trist. "The Evolution of Socio-Technical Systems." In Perspectives on Organizational Design and Behavior. Edited by A.H. Van de Ven and W.F. Joyce. New York: John Wiley, I98I.

E. Trist and C. Dwyer. "The Limits of Laissez-Faire as a Socio-Technical Change Strategy." In The Innovative Organization: Productivity Programs in Action. Edited by R. Zager and M. Rosow. New York and Oxford: Pergamon Press, 1982.

Library of Congress Cataloging-in-Publication Data

The Social engagement of social science.

Includes bibliographical references and indexes.

Contents: v. I. The socio-psychological perspective - v. 2. the socio-technical perspective.

I. Social psychology. 2. Social psychiatry. I. Tavistock Institute of Human Relations.

II. Trist, E. L. III. Murray, Hugh, Dr.

HM25I.S67124 I990 $302 \quad 89-28856$

ISBN 0-8I 22-89I 2-6 (v. I)

ISBN 0-8I 22-8I93-4 (v. 2) 
These volumes are dedicated to DR. A.T. MACBETH WILSON

Founder Member and Chairman (1948-1958)

Tavistock Institute of Human Relations 
